Contents List available at RAZI Publishing

Geological Behavior (GBR)

Journal Homepage: http://www.razipublishing.com/journals/geological-behavior/

https://doi.org/10.26480/gbr.01.2017.06.09

\title{
Landslide Susceptibility Analysis (LSA) using Deterministic Model (Infinite Slope) (DESSISM) in the Kota Kinabalu Area, Sabah, Malaysia
}

Rodeano Roslee*1, Norbert Simon2, Felix Tongkul1, Mohd. Norazman Norhisham1 \& Mohd. Radzif Taharin1

1 Geology Programme, Faculty of Science and Natural Resources, University Malaysia Sabah,UMS Road, 88400 Kota Kinabalu, Sabah, Malaysia 2Department of Geology, Faculty of Science and Technology, University Kebangsaan Malaysia, 43600 Bangi, Selangor

*Corresponding Author Email Address: rodeano@ums.edu.my (Rodeano Roslee)

This is an open access article distributed under the Creative Commons Attribution License, which permits unrestricted use, distribution, and reproduction in any medium, provided the original work is properly cited

\section{ARTICLE DETAILS}

Article history:

Received 27 September 2016

Accepted 13 December 2016

Available online 10 January 2017

\section{Keywords:}

Deterministic slope stability (DSS) infinite slope model (ISM)

landslide susceptibility analysis (LSA)

failure probability

\section{ABSTRACT}

A practical application for landslide susceptibility analysis (LSA) based on two dimensional deterministic slope stability (infinite slope model) (DESSISM) was used to calculate factor of safety (FOS) and failure probabilities for the area of Kota Kinabalu, Sabah. LSA is defined as quantitative or qualitative assessment of the classification, volume (or area) and spatial distribution of landslides which exist or potentially may occur in an area. In this paper, LSA value can be expressed by a FOS, which is the ratio between the forces that make the slope fail and those that prevent the slope from failing. An geotechnical engineering properties data base has been developed on the basis

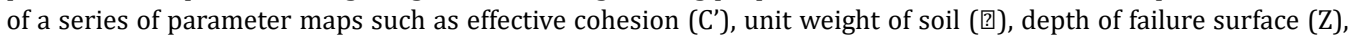
height of ground water table ( $\mathrm{Zw}), \mathrm{Zw} / \mathrm{Z}$ dimensionless (m), unit weight of water (⿴囗⿰丨丨⿱ $\mathrm{w}$ ), slope surface inclination $(\beta)$ and effective angle of shearing resistance (回). Taking into consideration the cause of the landslide, identified as groundwater change, the maximum groundwater level recorded corresponding to the actual situation of the most recent landslide is considered in this study. The highest probability value of the various scenarios was selected for each pixel and final LSA map were constructed. It has been found from this study that $\beta$ and $\mathrm{Zw}$ parameters have the higher influence on landslide instability. The result validation between the examined LSA map and result of landslide distribution map (LDM) were evaluated. This DESSISM had higher prediction accuracy. The prediction accuracy is $84 \%$. The resulting LSA maps can be used by local administration or developers to locate areas prone to landslide area, determine the land use suitability area and to organize more detailed analysis in the identified "hot spot" areas.

\section{INTRODUCTION}

Landslides are amongst the most damaging natural hazards in the world. The study of landslides has drawn worldwide attention mainly due to increasing awareness of the socio-economic impact of landslides, as well as the increasing pressure of urbanization. The term "zonation" in a general sense implies a division of the land into areas and their classification according to degrees of actual or potential landslide hazard or susceptibility (Varnes 1984). The purpose of landslide susceptibility analysis (LSA) is to highlight the regional distribution of potentially unstable slopes based on a detailed study of the factors responsible for landslide (Aleotti \& Chowdhury 1999; Ayalew et al. 2005). LSA is defined as quantitative or qualitative assessment of the classification, volume (or area) and spatial distribution of landslides which exist or potentially may occur in an area (International Society of Soil Mechanics and Geotechnical Engineering (ISSMGE), www. engmath.dal.ca/tc32). Susceptibility may also include a description of the velocity and intensity of the existing or potential landsliding.

In literature, various approaches to geotechnical deterministic analysis for LSA have been developed. Some of the earliest studies in a GIS environment were carried out by Okimura \& Kawatani (1986); van Westen (1993); Montgomery \& Dietrich, (1994); Dietrich et al. (1995); Terlien et al. (1995), van Westen \& Terlien (1996) and Dymond et al. (1999). Their use of a GIS environment made it possible to extend the conventional, site specific deterministic model into larger areas, where the spatial distribution of input parameters is taken into account. However, Corominas \& Santacana (2003); and Crosta \& Dal Negro (2003) observed that geotechnical approaches for LSA in a GIS environment have not been checked with traditional methods of analysis, neither have they been validated with results of landslide monitoring. Comprehensive studies concerning regional slope stability assessment supported by deterministic approaches in a GIS environment have also been carried out. Pack et al. (1998) and Zaitchik et al. (2003) combine a slope stability model (Stability INdex MAPping, SINMAP) with a steady-state hydrology model in selected watersheds of northern Vancouver Island, British Columbia and in the central highlands of Honduras, respectively. High attention should be paid to the accuracy and variability associated with the input parameters. Similar examples of regional modeling and prediction of shallow landslides using a transient rainfall infiltration model in combination with slope stability calculation (Transient Rainfall Infiltration and Grid-based Regional Slope-stability analysis; TRIGRS

were applied for the Seattle area, Washington State, USA (Baum et al. 2005) and the Umbria Region, central Italy (Salciarini et al. 2006). The TRIGRS model predicts a larger area of instability than the area that actually failed, mainly due to uncertainty in soil thickness, local variation in soil properties, and Digital Elevation Model (DEM) errors.

\section{Materials and Method}

The LSA degree can be expressed by the FOS, which is the ratio between the forces that make the slope fail and those that prevent the slope from failing. F-values larger than 1 indicate stable conditions, and vice-versa (Table 1). At $\mathrm{F}=1$ the slope is at the point of failure. Many different models exist for the calculation of FOS. Here we will use one of the simplest models, the so-called deterministic slope stability (infinite slope model) (DESSISM)). This two dimensional model describes the slope stability of slopes with an infinitely large failure plane. It can be used in a GIS, as the calculation can be done on a pixel basis. The pixels in the parameter maps can be considered as homogeneous units. The effect of the neighboring pixels is not considered, and the model can be used to calculate the stability of each individual pixel, resulting in a hazard map of FOS. The FOS is calculated according the following formula (Brunsden \& Prior, 1979; in: van Westen \& Terlien, 1996):

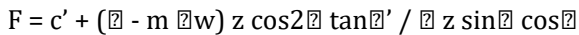

in which:

$\mathrm{c}^{\prime}=$ effective cohesion $(\mathrm{kPa}=\mathrm{kN} / \mathrm{m} 2)$.

$\gamma=$ unit weight of soil $(\mathrm{kN} / \mathrm{m} 3)$.

$\mathrm{z}=$ depth of failure surface below the surface $(\mathrm{m})$.

$\mathrm{zw}=$ height of groundwater table above failure surface $(\mathrm{m})$.

$\mathrm{m}=\mathrm{zw} / \mathrm{z}$ (dimensionless).

$\gamma \mathrm{w}=$ unit weight of water $(\mathrm{kN} / \mathrm{m} 3)$.

$\beta=$ slope surface inclination $\left(^{\circ}\right)$.

Q ${ }^{\prime}=$ effective angle of shearing resistance $\left({ }^{\circ}\right)$.

The DSS-ISM can be used either on profiles as well as on pixels, as shown in figure 1 . The entire analysis requires first the preparation of the data base. Since this is not available for the Kota Kinabalu area, the process will be simplified. 


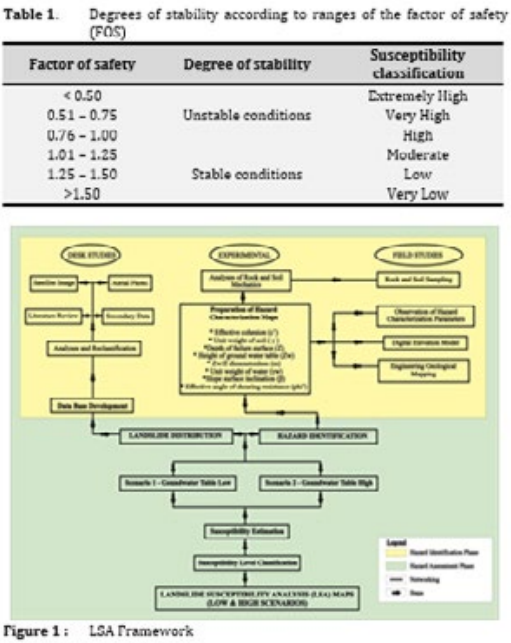

\subsection{Phase 1: Landslide Hazard Identification Phase (LHIP)}

Phase 1 residing within figure 1 is the preliminary stages in landslide hazard assessment consisting of Landslide hazard identification phase (LHIP). LHIP involved three (3) main types of research namely desk studies, field studies and laboratory studies. The desk studies involved the aerial photograph interpretation and satellite images (Erdas V.9.2 software) analyses in detail, and extensive studies on literature review and secondary data collections. All of these sources will be analyses and reclassified to get an idea or preliminary information about the landslide distribution and historical data aspects in the study area. Products from this desk studies is to establish data base for landslide incidents background and to generate the "Landslide Distribution Map" (LDM) for the study area by using Arc GIS V.9.3 software. On the other hand, field studies in LHIP involving sampling of rocks and soils, engineering geology mapping, , and observation hazard characterization parameters and extracting digital elevation model. For laboratory studies in LHIP, all samples of rocks and soils obtained from the field will be analyzed and evaluated for their engineering properties in accordance to the standards recommended by the ISRM $(1979 ; 1979 b$ \& 1985) and BS1377-1990 (Method of Test for Soils for Civil Engineering Purposes) such as the direct shear test for rock testing's and the classification of grain size, Atterberg limit, and triaxial test (Consolidated isotropically undrained, CIU) for soil testing's. After all the laboratories studies were completed, a several thematic maps for LHIP will be produced such as such as effective cohesion

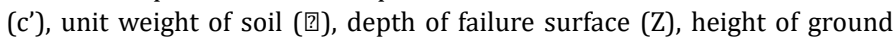
water table $(\mathrm{Zw}), \mathrm{Zw} / \mathrm{Z}$ dimensionless $(\mathrm{m})$, unit weight of water ( $(\mathrm{g} w)$, slope surface inclination $(\beta)$ and effective angle of shearing resistance (回).

\subsection{Phase 2: Landslide Hazard Assessment Phase (LHAP)}

In phase 2, taking into consideration the cause of the landslide, identified as groundwater change, the maximum groundwater level recorded corresponding to the actual situation of the most recent landslide is considered. A simple method for error propagation was used to calculate the variance of the FOS based on equation (1) and the probability that will be less than 1 for each pixel. The slope stability calculation is carried out by a combination of the input parametric maps with the GIS operations using a grid base. Finally, the resultant LSA maps are compared and validated with the data from LDM. The highest probability value of the various scenarios was selected for each pixel and final LSA map was constructed. Because the FOS in the final LSA map is assigned as a single value in every cell of a raster map, it is convenient to perform a reclassification of the calculated values (Table1).

3. Result and Discussion

\subsection{Geological Background}

Geological map portraying information about the main geological units (Figure 2). The different rock compositions and textures affect slope instability, influencing strength, permeability, and susceptibility to chemical and physical weathering of the rock masses. These map also representing the structural setting of the study area. Features such as sequence and type of layering, lithologic changes, planes, joints, faults and folds are accountable for LSA. The exposed rocks in the study area and its surrounding vary in types and ages, from Late Eocene-Early Miocene sandstone and shale of Crocker
Formation to Young Alluvial sediments which are still being deposited (Rodeano et al., 2006). The sandstone-siltstone-shale unit is defined by an interbedded sandstone and shale with occasional siltstone. The thickness of the individual beds ranges from $2 \mathrm{~cm}$ to $130 \mathrm{~cm}$. The sandstone is normally fine to very fine-grained and highly fractured while the shale layers are sheared. The shale unit is generally composed of red and grey types of shale. The grey variety is occasionally calcareous. This alternating sequence is commonly interbedded with siltstone or very fine grained sandstone. The shale comprises about $12 \%$ of the total volume of Crocker Formation. The sandstone composition is dominated by quartz with subordinate amounts of feldspars and chloritized, illitized or silicified lithic fragments. Calcareous fractions are rare. These are poorly sorted and well compacted with the pores filled by fine grained detritus or squeezed lithoclasts resulting in very low to nil primary porosity. The sandstone unit is characterized by very low to nil porosity but moderate to high secondary permeability. It is defined by its great thickness, medium to very coarse-grained and sometime pebbly. Thin shale or siltstone bed between 3 to $40 \mathrm{~cm}$ thicknesses occurred between the thick sandstone beds. The argillaceous beds are frequently site of shearing while the sandstone beds site of fracturing or jointing. The alluvium is restricted to the low land. It mainly represent unconsolidated alluvial sediment on river terraces and flood plains composed of unsorted to well-sorted, sand, silt and clay of varying proportions which were derived from upstream bed rocks. They occur in irregular lenses varying in the form and thickness. Towards the coastal area, the alluvium becomes finer-grained and interbedded with argillaceous deltaic and marine strata. The alluvium may also consist of very thin layer of organic matter. The alluvium sediment is soft, compressible and may be prone to settlement.

\subsection{Soil Types}

Map of soils describing the types and physical characteristics of unconsolidated deposits. Based on soil types map obtained from the Jabatan Pertanian (Sabah), the soil association can be categories into ten (10) associations namely Weston association, Tanjung Aru association, Tuaran association, Kinabatangan association, Sapi association, Klias association, Brantian association, Dalit association, Lokan association, and Crocker association (Figure 3).

\subsection{Landslide Distribution}

Landslide distribution is very useful information to study the physical changes and the latest geological assessment of their vulnerability. It's quantified all the information for any complex phenomenon. In these studies, landslides were classified in terms of types, materials involved, estimated volumes and velocities, degrees of activity, and return periods; distinctions were made between source and depositional areas. Approximately about 193 landslide locations have been identified through the extensive of review of literature, aerial photograph interpretations and field studies (Figure 4). The types of landslide were classified into several types; $20 \%$ of the fall, $30 \%$ of the translational, $20 \%$ of rotational, $15 \%$ of the flow, and $15 \%$ of the complex (a combination of fall, slide and/or flow). In terms of landslide scale, the study area consists of small ( $<50 \mathrm{~m} 3)(20 \%)$, medium $(50 \mathrm{~m}-500$ m3) (60\%) and large (>500 m3) (20\%).

\subsection{Digital elevation model (DEM)}

A digital elevation model (DEM) with grid cells $10 \mathrm{~m} \times 10 \mathrm{~m}$ produced based on raster data set of the slope conditions provided by raster datasets on morphometric features (altitude, internal relief, slope angle, aspect, longitudinal and transverse slope curvature and slope roughness) and on hydrologic parameters (watershed area, drainage density, drainage network order, channel length, etc.) were automatically extracted from the DEM (Figure 5). In terms of slope gradient, the resulted suggests that 49 $\%$ of the area can be categorised as " $0 \mathrm{o}-200$ ", $5 \%$ as " $210-40 \mathrm{o}^{\text {", }} 33 \%$ as " $41 \mathrm{o}-60 \mathrm{o}$ ", $12 \%$ as " $61 \mathrm{o}-80 \mathrm{o}$ " and $1 \%$ as "more than $80 \mathrm{o"}$ ". More than 40 o of slope gradient categories represent the very steep slope segments in the study area. Geotechnical engineering properties of seventy two (72) soil samples indicated that the soil materials mainly consist of poorly graded to well graded materials of clayey, silty to sandy soils, which are characterized by low to high plasticity, effective cohesion ( $\mathrm{c}^{\prime}$ ) ranges $4.67 \mathrm{kPa}$ to $18.03 \mathrm{kPa}$ (Figure 6), unit weight of soil (国) ranges from $7.66 \mathrm{kN} / \mathrm{m} 3$ to $20.44 \mathrm{kN} /$ $\mathrm{m} 3$ (Figure 7), depth of failure surface (Z) ranges from $3.85 \mathrm{~m}$ to $27.09 \mathrm{~m}$ (Figure 8), height of ground water table ( $\mathrm{Zw}$ ) ranges from $0.00 \mathrm{~m}$ to 2.93 $\mathrm{m}$ (Figure 9), $\mathrm{Zw} / \mathrm{Z}$ dimensionless (m) ranges from 0.00 to 11.30 (Figure 10 ), effective angle of shearing resistance (回) ranges from $1.70 \mathrm{o}$ to $26.07 \mathrm{o}$ (Figure 11), tan? ranges from -5.540 to 2.28 o (Figure 12), slope surface 
inclination ( $\beta$ ) ranges from 0 o to 67.57o (Figure 13); and $\sin \beta, \cos \beta$ and $\cos 2 \beta$ ranges from -1 o to 1 o (Figures 14 to 16 ).

3.6 Landslide Susceptibility Analysis (LSA)

After all thematic maps in phase 1 (LHIP) were produced, all of these parameters are compiled and compute according to the equation (1) and reanalysed together with LDM to generate a new thematic map known as "Landslide Susceptibility Analysis (LSA) map" (Figures 19). The resultant LSA map provided a relative assessment of the landslide area using the FOS. The LSA map suggests that areas of VLS to LS were $33 \%$ and $12 \%$; and areas of MS to EHS were $29 \%$ of MS, $8 \%$ of HS, $8 \%$ of VHS and $10 \%$ of EHS. The LSA map indicate that $\beta$ and Zw parameter factors have the highest influence on landslide instability. In general, VLS to MS areas (FOS $=>1.00$ ) is refer to the stable conditions with flat to moderately steep slopes with pasture and this area is highly recommended to do any future planning development (Table 2). In contrast, HS to EHS areas (FOS $=<1.00$ ) represent the unstable conditions with steep slope segments. HS to VHS areas basically was not recommended to be developed due to geological, hydrological and geotechnical constraints. However, if there is no choice or the developer or the local authorities really want to develop this area, some procedures to be observed as stated in Table 2. EHS area strictly was not recommended to be developed and should have provisions, suitable nonstructural works planning control as shown in Table 2 are recommended.

\subsection{Verification of the Landslide Susceptibility Map}

For validation of landslide susceptibility calculation models, two basic assumptions are needed: (1) landslides are related to spatial information, such as topography and geology, and (2) future landslides will be precipitated by a specific impact factor such as rainfall or earthquake (Brabb, 1984; Chung \& Fabbri, 1999; Varnes 1978). In this study, the two assumptions are satisfied because the landslides were related to the spatial information, and the landslides were precipitated by one causeheavy rainfall in the study area. The LSA result was validated using known landslide locations. Verification was performed by comparing the known landslide location data (Figure 4) with the LSA map (Figure 17). The comparison is shown in Figure 18 for the maximum of groundwater level model (LSA). Figure 18 illustrates how well the estimators perform with respect to the landslides used in constructing those estimators. To obtain the relative ranks for each prediction pattern, the calculated index values of all cells in the study area were sorted in descending order. The success rate validation results were divided into 100 classes with accumulated $1 \%$ intervals, according to the landslide susceptibility index value. As a result, considering all the factors used in the study area, the $90-100 \%(10 \%)$ class, with the highest possibility of landslide, contains $60 \%$ of the landslide grid cells in success rate using the maximum (LSA) of groundwater level models and so on until the calculation of $0 \%-100 \%(100 \%)$ of $100 \%$ of the total area in the rates obtained in this model, respectively. In the case of the $80-100 \%(20 \%)$ class, this contains $70 \%$ of the area in success rate using the maximum (LSA) of groundwater level model. To compare the result quantitative, the areas under the curve were re-calculated as if the total area is 1 which means perfect prediction accuracy (Lee \& Dan, 2005). So, the area under a curve can be used to assess the prediction accuracy qualitatively. The area ratios were 0.84 , and we could say the prediction accuracy is $84 \%$ (Figure 18). Overall, the maximum (LSA) of groundwater level model used showed a high accuracy.

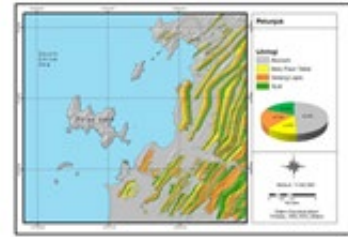

Figure 2 : Geological map

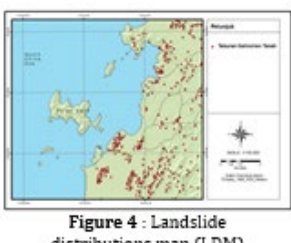

Figure 4 : Landslide
distributions map (LDM)

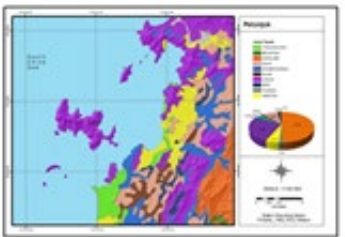

Figure 3 : Soil types map

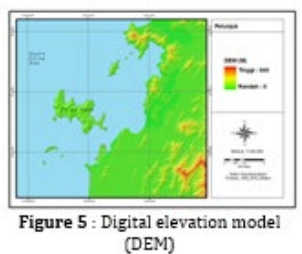

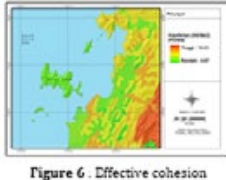

(c) map
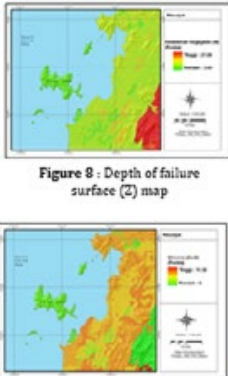

Figure $10: 3 \mathrm{w} / 2$
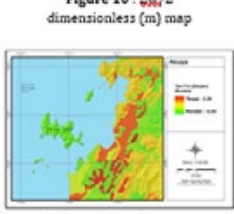

Figure 12 : tant map
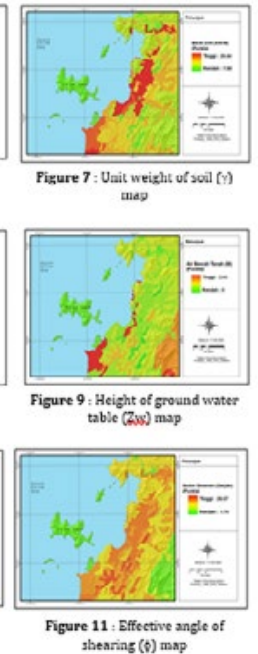

Figure 11: : Effective and
ghearing $(\ell)$ map
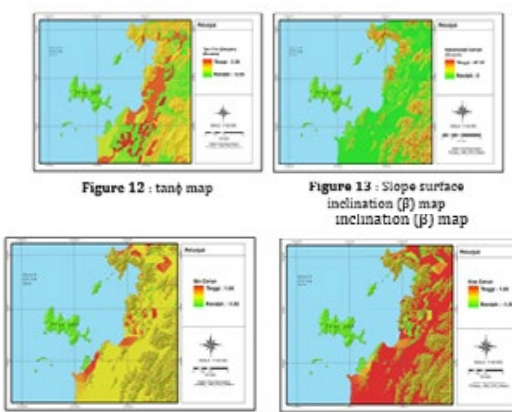

Figure $14: \sin \beta$ map
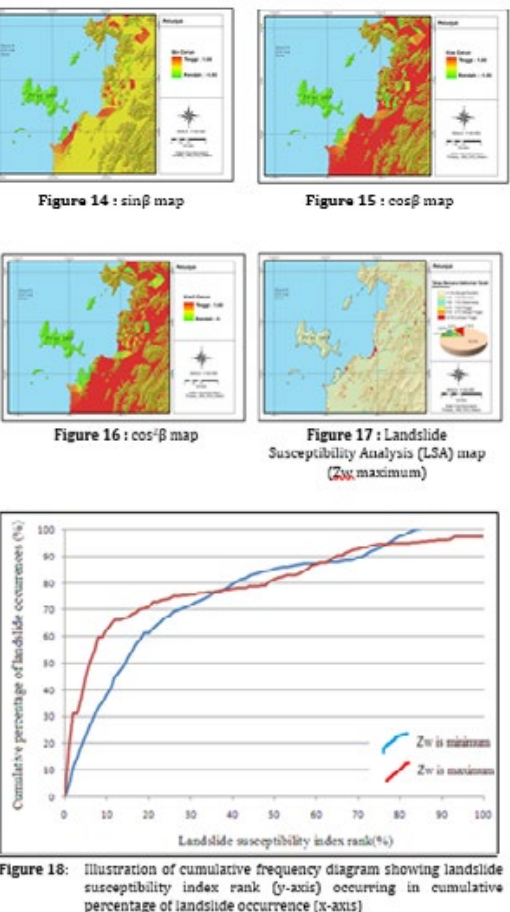

4. Conclusions

In light of available information, the following conclusion may be drawn from the present study:

1. LSA map indicate that slope surface inclination $(\beta)$ and height of ground water table (Zw) parameter factors have the higher influence on landslide instability.

2. The benefit of a DESSISM is to provide insight and options for decision-making in practical problems. The benefits includes:

- It encourages a rational, systematic approach for assessing the safety of slopes, and a framework to put uncertainties and engineering judgment into a system and allows comparison of hazard and risk for different slopes. LSA study allows collecting, management, analysis and
dissemination of a large amount of data, widespread in the region. All of these actions, based on continuous scientific and technologic research, with a strong multidisciplinary component and the involvement of local, regional, and interregional authorities, allow effective regional land-use planning

3. This DESSISM had higher prediction accuracy. The prediction accuracy is $84 \%$.

GIS geospatial technology capability of LSA provides a valuable tool for gaining susceptibility level estimates at the regional scale. This result 
highlights the importance of the potential effects of landslides in the study area. The resulting LSA can be used by local administration or developers to locate areas prone to landslide area, determine the land use suitability area, to organize more detailed analysis in the identified "hot spot" areas and can manage the impact of landslide disaster that may affect the regional economy (loss and damage to property) or welfare of the community (deaths and homeless) (risky areas).

\section{Acknowledgements}

A lot of thanks to the Universiti Kebangsaan Malaysia (UKM) and Universiti Malaysia Sabah (UMS) on ease of use in laboratories and research equipments and the Ministry of Education (MOE) on scholarship Bumiputera Academic Training Scheme (SLAB) to author1 an extensive in terms of financial help during this study. The highest appreciation is also given to the KPT on fundamental research grant award (FRG0258/SS22010) to finance all costs of research.

\section{References}

[1] Baum, R.L., Coe, J.A., Godt, J.W., Harp, E.L., Reid, M.E., Savage, W.Z., Schulz, W.H., Brien, D.L., Chleborad, A.F., McKenna, J.P. \& Michael, J.A., 2005. Regional landslide-hazard assessment for Seattle, Washington, USA. Landslides 2(2): 266-279.

[2] Brabb, E.E. 1984. Innovative approach to landslide hazard and risk mapping. Proc. of the 4th international symposium on landslides. Toronto, Canada. 1:307-324

[3] British Standard BS 1377.1990. Methods of Test for Soils for Civil Engineering Purposes. London: British Standard Institution.

[4] Chung, C.F. \& Fabbri, A.G. 1999. Probabilistic prediction models for landslide hazard mapping. Photogrammetric Eng Remote Sens. 65:1389-1399.

[5] Corominas, J. \& Santacana N, 2003. Stability analysis of the Vallcebre translational slide, Eastern Pyrenees (Spain) by means of a GIS. Nat Hazards (Dordr) 30(3): 473-485.

[6] Crosta, G.B. \& Dal Negro, P., 2003. Observations and modelling of soil slip-debris flow initiation processes in pyroclastic deposits: the Sarno 1988 event. Natural Hazards and Earth System Sciences 3(1-2): 53-69.

[7] Dietrich, W.E., Reiss, R., Hsu, M.L. \& Montgomery, D.R., 1995. A process-based model for colluvial soil depth and shallow landsliding using digital elevation data. Hydrological Process 9: 383-400.

[8] Dymond, J.R., Jessen, M.R. \& Lovell, L.R., 1999. Computer simulation of shallow landsliding in New Zealand hill country. International Journal of Applied Earth Observation and Geoinformation 1(2): 122-131.

[9] ISRM, 1979. Suggested methods for determining water content, porosity, density, absorption and related properties, and swelling and slake-durability index properties. ISRM Commission on Standardization of Laboratory and Field Tests. Int. J. Rock Mech. Min. Sci. 16: 141-156.

[10] ISRM, 1979b. Suggested methods for determining the uniaxial compressive strength and deformability of rock materials. ISRM Commission on Standardization of Laboratory and Field Tests. Int. J. Rock Mech. Min. Sci. 16: $135-140$

[11] ISRM, 1985. Suggested methods for determining point load strength. ISRM Commission on Standardization of Laboratory and Field Tests. Int. J. Rock Mech. Min. Sci. 22 (2): 51-60.

[12] Lee, S. \& Dan, N.T. 2005. Probabilistic landslide susceptibility mapping in the Lai Chau province of Vietnam: focus on the relationship between tectonic fractures and landslides. Environ. Geol. 48:778-787.

[13] Montgomery, D.R. \& Dietrich, W.E., 1994. A physically-based model for the topographic control on shallow landsliding. Water resources research 30: 1153-1171.

[14] Okimura, T. \& Kawatani, T., 1986. Mapping of the potential surface-failure sites on granite mountain slopes. In: Gardiner V (ed.). Int Geomorp Part I. Wiley, New York, 121-138.

[15] Pack, R.T., Tarboton, D.G., Goodwin \& C.N., 1998. The SINMAP approach to terrain stability mapping. In: Moore, D.P. \& Hungr, O. (eds) 8th Congress of the International Association of Engineering Geology. Vancouver, British Columbia, 21-25 September 1998, 1157-116.

[16] Rodeano, R., Sanudin, T. \& Shariff, A.K.S.O. 2006. Engineering geology of the Kota Kinabalu area, Sabah, Malaysia. Bull. of Geol. Society of Malaysia 52: 17- 25.

[17] Salciarini, D., Godt, J.W., Savage, W.Z., Conversini, P., Baum, R.L. \& Michael, J.A., 2006. Modeling regional initiation of rainfall-induced shallow landslides in the eastern Umbria Region of central Italy. Landslides 3(3):181-194.
[18] Terlien, M.T.J., Van Asch, T.W.J. \& Van Westen, C.J., 1995. Deterministic modelling in GIS-based landslide hazard assessment. In: Carrara, A., \& Guzzetti, F. (eds), Geographical information systems in assessing natural Hazards. Kluwer Academic Publishing, The Netherlands, 57-77 pp.

[19] van Westen, C.J., 1993. GISSIZ. Training package for geograophic infromation systems in slope instability zonation. Part 1: theory. UNESCOITC Project on "Geo-information for environmentally sound management of natural resources". Enschede, Netherlands.

[20] van Westen, C.J. \& Terlien, M.T.J., 1996. An approach towards deterministic landslide hazard analysis in GIS. A case study from Manizales (Colombia). Earth Surf Processes Landf. 21(9): 853-868.

[21] Varnes, D.J.1978. Slope movement types and processes, landslides analysis and control. Special Report 176. Transportation Research Board, Washington, DC, 11-80.

[22] Zaitchik, B.F., van Es, H.M. \& Sullivan, P.J., 2003. Modeling slope stability in Honduras: parameter sensitivity and scale of aggregation. Soil Sci Soc Am J 67(1): 268-278. 